\title{
Ultrastructure of sporulation in Haplosporidium armoricanum
}

\author{
P. M. Hine ${ }^{1, *}$, M. Y. Engelsma ${ }^{2}$, St. J. Wakefield ${ }^{3}$ \\ ${ }^{1}$ Investigation and Diagnostic Centre, Biosecurity New Zealand, Ministry of Agriculture and Forestry, PO Box 40-742, \\ Upper Hutt 6007, New Zealand \\ ${ }^{2}$ CIDC-Lelystad, Central Institute for Animal Disease Control, PO Box 2004, 8203 AA Lelystad, The Netherlands \\ ${ }^{3}$ Wellington School of Medicine, University of Otago, Private Bag 7902, Wellington South, New Zealand
}

\begin{abstract}
An ultrastructural study was carried out on the tissues of an oyster (Ostrea edulis), heavily infected with Haplosporidium armoricanum (van Banning, 1977), that had been fixed in Carson's fixative. The well-fixed tissues revealed details of sporulation and of the spores, which had not been previously reported from $H$. armoricanum. These include the initial presence of sparse haplosporosomes after thickening of the plasma membrane in early sporonts, division of sporont nuclei by multiple fission, cup-like indentations in the nuclear surface associated with putative nuclear material in both the sporonts and spores, and cytoplasmic multi-vesicular bodies in the cytoplasm of sporonts and spores. The spore wall and operculum were formed from a light matrix that occurred in short cisternae of smooth endoplasmic reticulum in the episporoplasm, and parallel bundles of microfibrils were present in some spores. Spores were rarely bi-nucleate with the nuclei occurring as a diplokaryon, with putative nuclear material at the junction of the 2 nuclei. Nuclear membrane-bound Golgi (NM-BG) cisternae were common in spores, and they appeared to synthesise a light granular material into lysosome-like granules. Dense bodies similar to those reported from $H$. lusitanicum, $H$. pickfordi and $H$. monforti occurred in, or outside, the peripheral endosporoplasm, which was closely apposed to the spore wall. Spore haplosporosomes were frequently axehead-shaped, more like those of $H$. costale than those previously reported from $H$. armoricanum, and in some haplosporosomes there was a small round lucent patch with a dark point near the centre of the lucent patch. Overall, $H$. armoricanum appears to be closely related to $H$. costale and Bonamia spp. Although the endosporoplasm of $H$. armoricanum has NM-BG and it resembles the uni-nucleate stage, it appears to be unlikely that they are the same, as the axehead-shaped haplosporosomes of the spore differ considerably from the spherical haplosporosomes of vegetative stages.
\end{abstract}

KEY WORDS: Haplosporidium armoricanum · Ultrastructure $\cdot$ Sporulation $\cdot$ Golgi $\cdot$ Haplosporogenesis

\section{INTRODUCTION}

Haplosporidium armoricanum was originally described as Minchinia armoricana from Ostrea edulis imported into The Netherlands from St Philibert, Brittany, France, but only the spore was illustrated (van Banning 1977). Subsequently, Pichot et al. (1979) described spores of a very similar parasite from $O$. edulis in France, but named it Haplosporidium sp., and did not regard it as definitely the same as $M$. armoricana. Cahour et al. (1980) described the diplokaryon, process of formation of the sporoplasm and the epi- sporoplasm, and the spore of $M$. armoricana from île Tudy, France. The spore ornamentation of $M$. armoricana was described by Perkins \& van Banning (1981), and was shown to differ from Urosporidium jiroveci and Haplosporidium louisiana. Subsequently, Vivarès et al. (1982) described the vegetative stages (uninucleate, bi-nucleate, plasmodia) of a haplosporidian from $O$. edulis from St Philibert, but in the absence of spores, did not attempt to name it. Uni-nucleate, diplokaryotic, early sporont and spore stages of a haplosporidian from $O$. edulis on the Mediterranean coast of France, with spore ornamentation placing it in the 
genus Haplosporidium, was reported by Bachère \& Grizel (1983), who recognised its resemblance to $M$. armoricana, and re-named it as H. armoricanum. Subsequently, Bonami et al. (1985) described the vegetative stages of a haplosporidian, again in $O$. edulis from St Philibert, but again in the absence of spores, did not name it. Pichot (1986) described a Haplosporidium sp. in O. edulis from the Bassin d'Arcachon, France, and illustrated the developmental stages from diplokaryon to spores, but the illustrations presented are small and lack detail. A study on the ornamentation on the spores of $H$. armoricanum clearly places it within that genus (Azevedo et al. 1999). Therefore, except for the indistinct illustrations in Pichot (1986), the details of sporulation by $H$. armoricanum are unknown.

In June 2005, a stunted European flat oyster (Ostrea edulis) from the Oosterschelde in The Netherlands was found to be heavily infected with a Haplosporidium sp. that, on the basis of molecular evidence (M. Y. Engelsma, N. A. Stokes, P. M. Hine unpubl.), was identified as $H$. armoricanum. The oyster was fixed in Carson's fixative (Carson et al. 1973), and subsequently fixed for transmission electron microscopy (TEM), and subsequent TEM showed the stages present, early sporont to spores, to be perfectly fixed. This study was therefore carried out because the quality of fixation permits several new observations on this species, and probably spore-forming haplosporidians in general, and the stages observed involve sporulation in $H$. armoricanum, which is currently poorly understood.

\section{MATERIALS AND METHODS}

In June 2004, European flat oysters Ostrea edulis were collected from commercial lots on the Yerseke Bank area in the Oosterschelde, The Netherlands. The oysters were collected by trawling with a $1 \mathrm{~m}$ wide dredge over $50 \mathrm{~m}$. A transverse section of the tissue, including digestive diverticulum, mantle and gills, was fixed in Davidson's solution for routine haematoxylin and eosin (H\&E) staining. Additional tissue of each oyster was fixed in $95 \%$ ethanol for DNA isolation and in Carson's fixative (Carson et al. 1973) for electronmicroscopic examination. In one of the collected oysters, Haplosporidium-like spores were observed by light microscopy. DNA was isolated from the ethanolfixed tissue of this individual, followed by PCR and sequencing of the $18 \mathrm{~S}$ ribosomal RNA of the parasite as described by M. Y. Engelsma, N. A. Stokes, P. M. Hine (unpubl.).

The heavily infected oyster (Ostrea edulis) was fixed for TEM by cutting it into small $<5 \mathrm{~mm}^{3}$ pieces, which were immediately placed in $2.5 \%$ glutaraldehyde buffered with $0.22 \mu \mathrm{m}$ filtered seawater (FSW), further cut into $\sim 1 \mathrm{~mm}^{3}$ pieces, fixed for $2 \mathrm{~h}$ at $18^{\circ} \mathrm{C}$, rinsed twice in FSW, post-fixed in $1 \% \mathrm{OsO}_{4}$ in $0.1 \mathrm{M}$ cacodylate buffer with $2 \%$ potassium ferrocyanide for $2 \mathrm{~h}$, and dehydrated for 10 min each in $15,30,50,70,80$, and $90 \%$ ethanol, followed by 3 changes for 20 min each in absolute ethanol. After $10 \mathrm{~min}$ in propylene oxide, $4 \mathrm{~h}$ in $50 \%$ propylene oxide $+50 \%$ Epon covered, then overnight uncovered, they were placed in fresh resin for $8 \mathrm{~h}$, embedded in fresh resin and heated in an oven at $60^{\circ} \mathrm{C}$, cut into semithin then ultrathin sections, and the grids examined on a Philips CM100 electron microscope.

\section{RESULTS}

The earliest stages observed were regarded as late plasmodia or early sporonts, as the plasma membrane was very folded, and had a dark coating $40 \mathrm{~nm}$ across. Spherical haplosporosomes, 200 to $269 \mathrm{~nm}$ in diameter, were occasionally present, but usually absent (Fig. 1, Table 1). Squarish to spherical nuclei frequently had their nuclear membranes closely apposed, suggesting recent division by fission, to leave nuclei with prominent nucleoli and bodies resembling mitotic spindle polar bodies (Fig. 1). Some nuclei had cup-like indentations of the nuclear membrane containing material resembling nucleolar material (Fig. 2), often adjacent to or between tightly apposed nuclear membranes. The cytoplasm contained long parallel profiles of smooth endoplasmic reticulum (sER), anastomosing endoplasmic reticulum (aER), many round to ovoid lipid droplets of various sizes, dense ribosomes, mitochondria with tubular cristae, and multi-vesicular bodies (MVBs) $0.4 \times 0.6 \mu \mathrm{m}$ in diameter (Fig. 1). In what may be later sporonts, the mitochondria had a swollen appearance, sometimes with a central vesicle, clustered around the nuclei. Long parallel sER arrays often surrounded mitochondria in sER/mitochondria complexes, and there were large arrays of sER, aER, MVBs, lipid droplets and moderately long lengths of sER in the cytoplasm (Fig. 3).

Late sporonts had irregular nuclei with nucleoli, swollen mitochondria closely around and sometimes indented in them, dilated cisternae of sER with a light matrix, sometimes in 2 to 3 parallel arrays resembling a simple Golgi, large amounts of aER, and a few lipid droplets (Fig. 4). Membranes formed around individual nuclei to delimit them as early sporoblasts, although the origin of the membranes was uncertain, it seemed most likely that short lengths of sER-like membrane joined together. The episporoplasm of spores was diagonal in shape, with spores developing in rows of alternating diagonals. The delimitation of the sporoplasm from the episporoplasm was not observed, but 

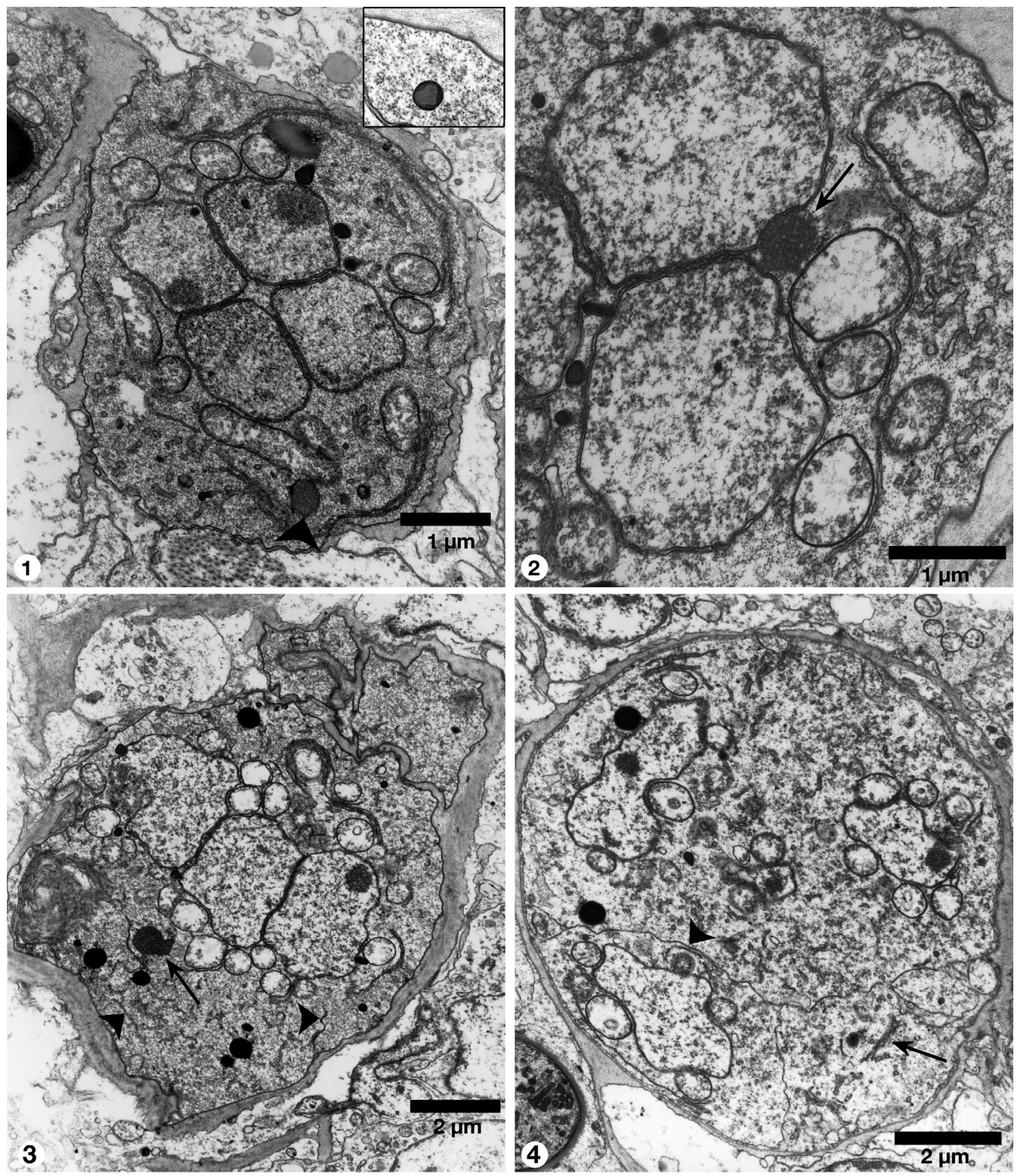

Figs. 1 to 4. Haplosporidium armoricanum. Fig. 1. An early sporont with 4 nuclei that may have divided by multiple fission. The cytoplasm contains mitochondria with tubular cristae, lipid droplets, a multi-vesicular body (MVB) (arrowhead), long parallel cisternae of smooth and anastomosing endoplasmic reticulum (sER and aER, respectively). Note the fibrillar layer around the sporont. Inset: a late plasmodial/early sporont haplosporosome, with a coated plasma membrane above it. Fig. 2. Part of a sporont showing putative nuclear material in slight indentations in the nuclear surface (arrow). Fig. 3. Late sporont showing nuclei that may have divided by multiple fission, ergastoplasm/mitochondrial complexes, mitochondria around the nuclei, aER, a large circular mass of SER, an MVB (arrow), membranes in the cytoplasm (arrowheads), and a thick fibrillar coating around the plasma membrane. Fig. 4. A late sporont or early sporocyst in which membranes delimit a sporoblast (arrowhead) Note the irregular shape of the sporoblast nucleus, with closely apposed mitochondria, large amount of sER/aER, lipid droplets, and Golgi-like cisternae (arrow) 
Table 1. Haplosporidium armoricanum. Dimensions and numbers of organelles

\begin{tabular}{|c|c|c|c|}
\hline Feature & Mean \pm SD & $\mathrm{n}$ & Range \\
\hline \multicolumn{4}{|l|}{ Sporont } \\
\hline Length $(\mu \mathrm{m})$ & $9.8 \pm 2.5$ & 6 & $6.9-13.9$ \\
\hline Width $(\mu \mathrm{m})$ & $7.9 \pm 1.9$ & 6 & $5.3-10.5$ \\
\hline Nucleus length $(\mu \mathrm{m})$ & $2.7 \pm 0.8$ & 12 & $1.5-3.7$ \\
\hline Nucleus width $(\mu \mathrm{m})$ & $2.0 \pm 0.6$ & 12 & $1.3-3.2$ \\
\hline No. of lipid droplets & $6.5 \pm 2.9$ & 6 & $3-11$ \\
\hline No. of mitochondria & $14.0 \pm 3.3$ & 6 & $10-19$ \\
\hline \multicolumn{4}{|l|}{ Spore } \\
\hline Length $(\mu \mathrm{m})$ & $4.1 \pm 0.4$ & 16 & $3.3-4.9$ \\
\hline Width $(\mu \mathrm{m})$ & $2.9 \pm 0.3$ & 16 & $2.5-3.4$ \\
\hline Length endosporoplasm ( $\mu \mathrm{m})$ & $3.6 \pm 0.4$ & 37 & $2.9-4.6$ \\
\hline Width endosporoplasm $(\mu \mathrm{m})$ & $2.8 \pm 0.3$ & 38 & $2.1-3.8$ \\
\hline Length episporoplasm $(\mu \mathrm{m})$ & $4.9 \pm 0.5$ & 32 & $4.0-6.2$ \\
\hline Width episporoplasm $(\mu \mathrm{m})$ & $3.8 \pm 0.5$ & 33 & $2.8-4.8$ \\
\hline Nucleus length $(\mu \mathrm{m})$ & $1.6 \pm 0.3$ & 23 & $1.2-2.5$ \\
\hline Nucleus width $(\mu \mathrm{m})$ & $1.3 \pm 0.2$ & 23 & $1.1-1.9$ \\
\hline No. of endospore lipid droplets & $0.4 \pm 0.5$ & 39 & $0-2$ \\
\hline No. of epispore lipid droplets & $0.3 \pm 0.8$ & 43 & $0-4$ \\
\hline No. of endospore mitochondria & $2.4 \pm 1.6$ & 35 & $0-5$ \\
\hline No. of epispore mitochondria & $2.1 \pm 1.8$ & 35 & $0-7$ \\
\hline Dense bodies (nm) & $136 \pm 24$ & 25 & $92-178$ \\
\hline No. of dense bodies & $3.2 \pm 2.1$ & 33 & $0-8$ \\
\hline Operculum width $(\mu \mathrm{m})$ & $2.7 \pm 0.4$ & 9 & $2.1-3.4$ \\
\hline Haplosporosome length (nm) & $176 \pm 41$ & 22 & $131-278$ \\
\hline Haplosporosome width (nm) & $143 \pm 29$ & 22 & $119-230$ \\
\hline Axe haplosporosome length (nm) & $613 \pm 147$ & 20 & $435-1037$ \\
\hline Axe haplosporosome shaft width (nm) & $122 \pm 14$ & 13 & $106-148$ \\
\hline Axe haplosporosome head width (nm) & $230 \pm 31$ & 20 & $170-290$ \\
\hline
\end{tabular}

and a few amorphous electron-dense bodies (herein called dense bodies) lacking a limiting membrane that were smaller than, but similar to, lipid droplets (Figs. 6 to 9). Dense bodies occurred in the cisternae of the spherule before haplosporogenesis, then became peripheral against the endosporoplasm plasma membrane. They also occurred in the space between the endosporoplasm and the spore wall, between the valves of the operculum, and in the episporoplasm (Figs. $7 \&$ 9).

In more mature spores the operculum was attached by a hinge to the spore wall, the spherule, which often resembled a large apical to equatorial mass of aER, rested below the operculum, and the round nucleus with polar bodies was posterior (Figs. 7 to 9). Cup-like indentations were occasionally seen in the nuclear surface (Fig. 7). Membrane-bound bodies formed in the spherule cisternae appeared to form into rod-like haplosporosomes <1037 nm long, which were shaped like an axehead at one end, tapering to a knob or wedge at the other (Table 1). In cross section the shaft of the rod was hollow,

putative endosporoplasm before the formation of the spore wall contained an ovoid to round nucleus with prominent nucleolus, a spherule comprised of aER, swollen mitochondria, and lipid droplets, but not haplosporosomes (Fig. 5). The episporoplasm contained dilated short sections of sER with a light matrix, long cisternae of sER, mitochondria and lipid droplets. However, development was not always consistent, with some sporocysts containing developing spores that showed initial deposition of spore wall and operculum, while the sER and aER were not fully organised into a spherule (Fig. 6). The spherule, which resembled a Golgi complex, seemed to originate from aER and sER derived from parallel cisternae of sER. Another simple Golgi was derived from the nuclear membrane (nuclear membrane-bound Golgi [NM-BG]) (Fig. 6).

The spore wall formed on the inner concave surface of the episporoplasm from the content of the dilated short cisternae with a light matrix, forming nodes that coalesced. The operculum initially developed in apical episporoplasm as a symmetrical disc, detached from the spore wall, and subsequently became domed in the centre. Immature sporoplasm contained a spherule, a round nucleus with eccentric nucleolus, 1 to 2 nuclear polar bodies, NM-BG, lipid, swollen mitochondria, granules with a moderately electron-dense content, with a wall $36 \mathrm{~nm}$ in diameter (Figs. 9 to 11). NM-BG were common (Figs. $7 \& 8$ ), and were often associated with granules, 189-243 × 216-378 nm in diameter, resembling lysosomes (Fig. 12). In some of the haplosporosomes of fully formed spores, there was a small round lucent patch with a dark point near the middle of the lucent patch (Fig. 8). Some spores contained parallel bundles of microfibrils which were often diagonal in the spore between the nucleus and the spherule/haplosporosomes (Fig. 9). Lipid was not common in sections of spores. Occasionally spores were bi-nucleate with the nuclei in a diplokaryon, and possibly putative nuclear material adjacent to the nuclei (Fig. 10). Some spores with a completely developed wall, hinged operculum, and large spherule lacked haplosporosomes, and may represent abnormal development.

Throughout development the episporoplasm contained sER cisternae, which usually contained a light matrix (Figs. 7 to 10), often occurring in Golgi-like parallel cisternae, with swollen mitochondria (Figs. 6 \& 8), dense bodies, and lipid droplets (Figs. 7 \& 9). External filaments were not observed in the episporoplasm at any stage. The spore wall was composed of 3 layers, an external light layer 19 to $30 \mathrm{~nm}$ across, a middle darker layer 37 to $74 \mathrm{~nm}$ across, and a light internal layer, 15 to $19 \mathrm{~nm}$ across. 

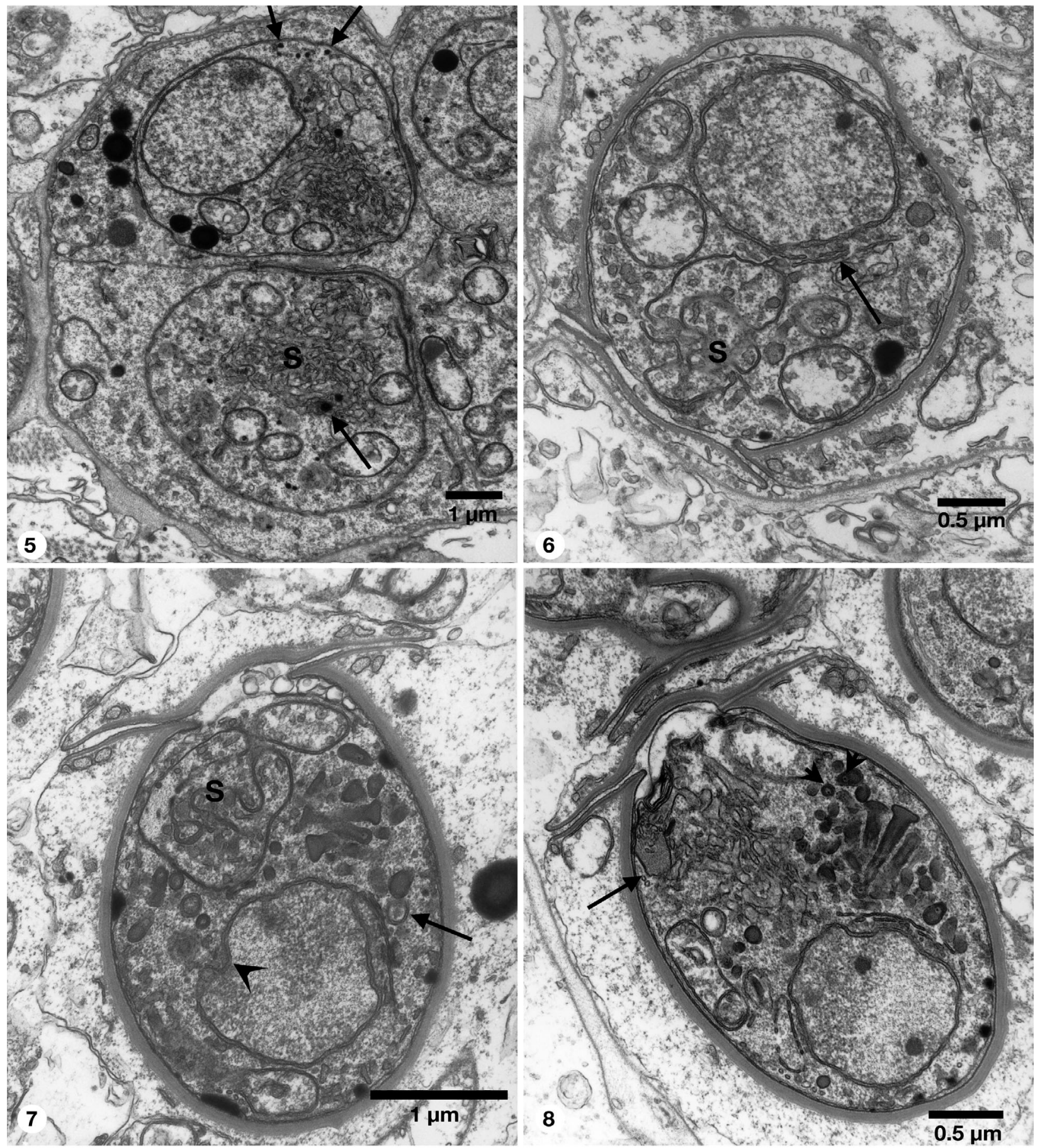

Figs. 5 to 8. Haplosporidium armoricanum. Fig. 5. Two very early spores showing the endosporoplasm containing a nucleus, spherule (s), small dense vesicles (arrows) in cytoplasm and in spherule cisternae, lipid droplets and mitochondria, but no haplosporosomes or spore wall. The episporoplasm contains mitochondria, lipid droplets, short smooth endoplasmic reticulum (sER) with light matrix, and long sER. Fig. 6. Developing spore with a polar body in the nucleus, nuclear membrane-bound Golgi (NM-BG) (arrowed), long profiles of sER, possibly arising from the NM-BG and in contact with the spherule (s), a granule with light matrix near the NM-BG, mitochondria and lipid but no haplosporosomes. In the episporoplasm sER with a light matrix rests against the developing spore wall and operculum. Fig. 7. Spore showing long cisternae of sER around spherule (s), cup-like indentation of the nuclear surface (arrowhead), NM-BG and adjacent haplosporosome-like body or circular profile of sER (arrow), haplosporosomes, peripheral dense vesicles, and vesicles under the operculum. The episporoplasm contains mitochondria, lipid droplets, and dilated sER with a light matrix by the operculum. Fig. 8. Spore showing the features seen in Fig. 6 , but also 2 NM-BG, 2 polar bodies, an MVB (arrow), and inclusions in the haplosporosomes (arrowheads) 


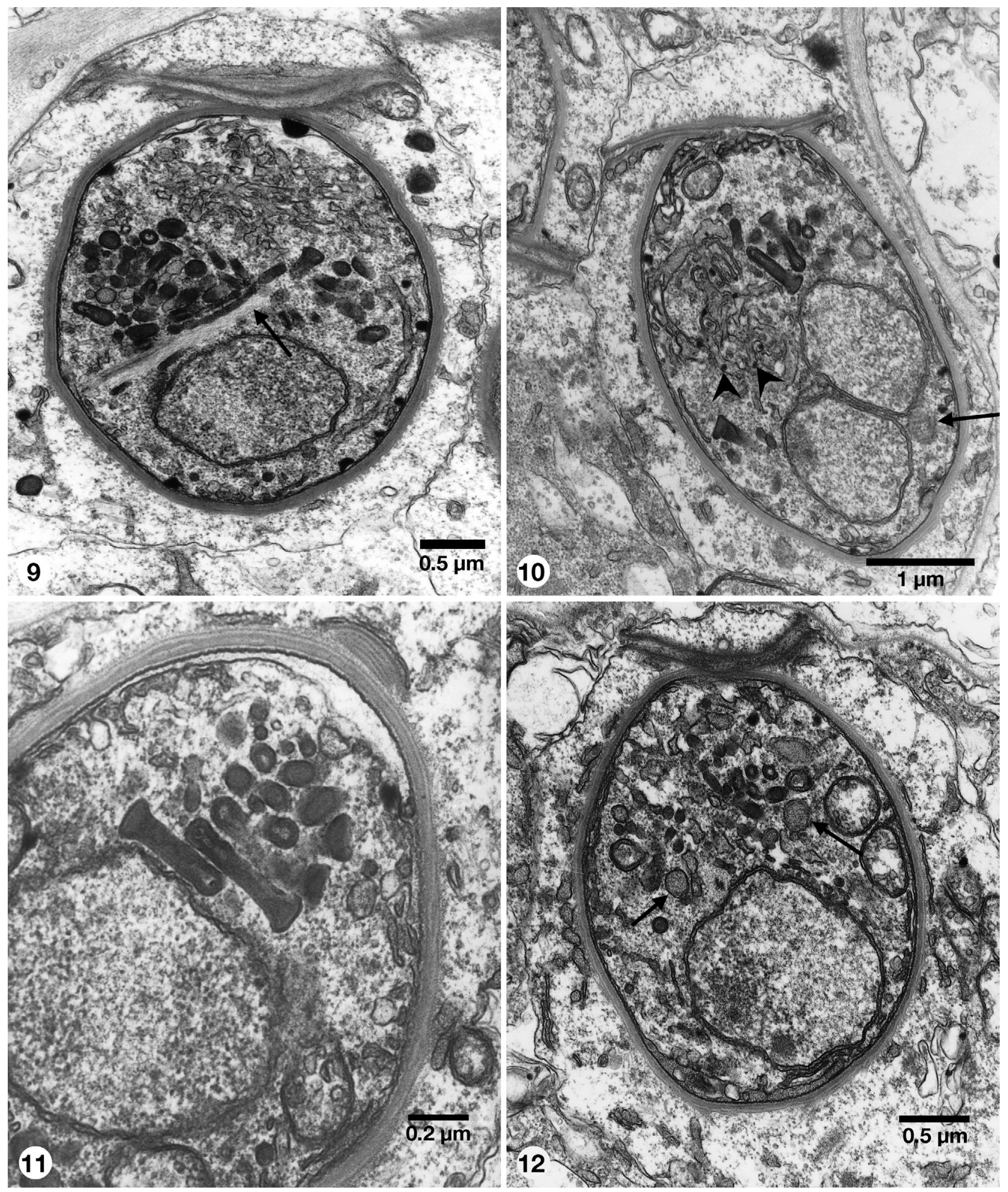

Figs. 9 to 12. Haplosporidium armoricanum. Fig. 9. A spore with a bundle of parallel microfibrils (arrow), a long dilated cisterna of smooth endoplasmic reticulum (sER) with a light matrix, and peripheral dense bodies, including one outside the endosporoplasm, beneath the operculum. Fig. 10. A diplokaryotic spore, with putative nuclear material at the junction of the nuclei (arrow), spherule cisternae with matrix containing small dark circular bodies (arrowheads), endosporoplasm sER parallel with the spore wall, and vesicles with light matrix in the episporoplasm. Fig. 11. Details of a spore showing the axehead-shaped haplosporosomes. Fig. 12. A spore with nuclear membrane-bound Golgi showing lysosome-like granules (arrows) 


\section{DISCUSSION}

Early sporonts are normally differentiated from late plasmodia by thickening of the plasma membrane concurrent with disappearance of haplosporosomes (Perkins 1968, 1969), and it has been suggested that the material thickening the plasma membrane derives from the haplosporosomes (Newman et al. 1976). In Haplosporidium armoricanum late plasmodia and early sporonts may have a folded thickened plasma membrane (Cahour et al. 1980, Vivarès et al. 1982). The nuclei of $H$. armoricanum sporonts may divide by multiple fission, which has only been reported in $H$. nelsoni (Fig. 10 in Perkins 1968), but which may also occur in Minchinia sp. infecting rock oysters (Bearham et al. 2007) (Fig. 10 in Hine \& Thorne 2002), rather than elongation and binary fission, normally observed in haplosporidian nuclei (Fig. 9 in Perkins 1968, Fig. 5 in Hine et al. 2001). Plasmodia or sporonts with cup-like indentations of the nuclear surface occur in a New Zealand abalone parasite (NZAP) (Fig. 2 in Hine et al. 2002), H. costale (Fig. 9 in Perkins 1969), Haplosporidium sp. from rock oysters (Fig. 10 in Hine \& Thorne 2002), and Bonamia exitiosa (Figs. 3 \& 4 in Hine 1991, Fig. 13 in Hine \& Wesney 1992), as well as in H. armoricanum (Fig. 4 in Cahour et al. 1980). However, this is the first report of cup-like indentations in the nuclear surface in spores. Nuclear polar bodies and aER (Cahour et al. 1980), clustering of mitochondria around the nuclei (Bonami et al. 1985), and ergastoplasm/ mitochondria complexes, have previously been described from the NZAP (Hine et al. 2002), H. armoricanum (Vivarès et al. 1982, Bachère \& Grizel 1983, Bonami et al. 1985), and from B. perspora (Carnegie et al. 2006). MVBs also occur in plasmodia of the NZAP (Hine et al. 2002) and B. exitiosa (see Hine \& Wesney 1992).

Sporoblasts are delimited by membranes that appear in the sporont cytoplasm in Haplosporidium armoricanum (Cahour et al. 1980, Pichot 1986), H. lusitanicum (see Azevedo et al. 1985), H. ascidiarum (see Ciancio et al. 1999) and Bonamia perspora (Carnegie et al. 2006). In other haplosporidians sporoblasts may be delimited by invagination of the sporont plasma membrane, or the formation of vacuoles that become joined (Perkins 1968, 1969, 1971, 1975, Anderson et al. 1993, Comps \& Tigé 1997, Hine et al. 2002). Nodal formation of the spore wall occurs in many, and probably all, Minchinia spp. and Haplosporidium spp., including H. armoricanum (Fig. 6 in Cahour et al. 1980). The formation of the spore wall and operculum from dilated cisternae of sER with a flocculent or granular matrix has been described from H. louisiana (Perkins 1975, Marchand \& Sprague 1979), and H. comatulae (La Haye et al. 1984), but not previously from $H$. armori- canum, although similar sER with matrix may occur in the uni-nucleate stage (Bonami et al. 1985). Pichot et al. (1979) described H. armoricanum spore wall formation as a stacking of leaflets, although this may describe the layers in the wall. The wall dimensions reported here are very different to the outer $(\mathrm{O})$, middle (M), and inner (I) layers reported by van Banning (1977) $(\mathrm{O}=60$ to $65 \mathrm{~nm}, \mathrm{M}=30$ to $32 \mathrm{~nm}, \mathrm{I}=123$ to $140 \mathrm{~nm})$, Cahour et al. (1980) $(\mathrm{O}=32 \mathrm{~nm}, \mathrm{M}=30 \mathrm{~nm}$, $\mathrm{I}=105$ to $160 \mathrm{~nm})$, and Bachère \& Grizel (1983) $(\mathrm{O}=$ $47 \mathrm{~nm}, \mathrm{I}>88 \mathrm{~nm}$ ). In the ultrastructurally similar spores of $H$. costale, the dimensions are $\mathrm{O}=10$ to $18 \mathrm{~nm}, \mathrm{M}=$ 10 to $16 \mathrm{~nm}$ and I $=57$ to $74 \mathrm{~nm}$ (Perkins 1969). The reason for variation among $H$. armoricanum is unknown, but if due to initial fixation in Carson's fixative, care must be taken when using spore wall dimensions in taxonomic studies. The bundles of microfibrils in the sporoplasm of $H$. armoricanum resembles those reported from Urosporidium spisuli (Perkins et al. 1975), Minchinia sp. (Bearham et al. 2007) (= Haplosporidium sp., Hine \& Thorne 2002), and B. perspora spores (Carnegie et al. 2006).

The spore spherule reported here resembles previous descriptions from Haplosporidium armoricanum (van Banning 1977, Pichot et al. 1979, Cahour et al. 1980, Bachère \& Grizel 1983, Pichot 1986), and it is generally regarded as a modified Golgi complex (Rosenfield et al. 1969, Perkins 1979). This is supported by the involvement of NM-BG in haplosporogenesis in vegetative stages of the NZAP (Hine et al. 2002), $H$. louisiana and H. nelsoni (see Perkins 1979), Bonamia exitiosa (Hine \& Wesney 1992), NM-BG are also known from $H$. armoricanum (Fig. 2 in Bonami et al. 1985), and spores of Urosporidium spisuli (Fig. 17 in Perkins 1979) and B. perspora (Carnegie et al. 2006), but this is the first time they have been reported in spores of $H$. armoricanum, in which they are common. NM-BG have not been reported from $H$. costale (Perkins 1969) or a H. costale-like organism (Comps \& Pichot 1991). Therefore, spores of $H$. armoricanum contain 2 separate and different Golgi compartments, the spherule forming dense bodies, and spherical, ovoid, and axehead-shaped haplosporosomes in the spore, and NM-BG forming spherical to ovoid haplosporosomes in vegetative stages (Bachère \& Grizel 1983, Bonami et al. 1985).

The spores illustrated by other authors vary in appearance, showing electron-light dense bodies/ haplosporosomes in a dense spore (van Banning 1977), an electron-light spore with spherical to ovoid haplosporosomes (Pichot et al. 1979, Bachere \& Grizel 1983), with dense bodies/haplosporosomes lateral to the nucleus (Pichot et al. 1979, Bachère \& Grizel 1983), and a dispersed spherule (Cahour et al. 1980, Bachère \& Grizel 1983). Haplosporidium armoricanum haplo- 
sporosome shape and size differs between studies and developmental stage. Uni-nucleate stages have round to ovoid haplosporosomes 130 to $320 \mathrm{~nm}$ in diameter (Bonami et al. 1985), and dense bodies 200 to $400 \mathrm{~nm}$ in diameter (Bachère \& Grizel 1983), plasmodia have haplosporosomes 130 to $350 \mathrm{~nm}$ in diameter (Vivarès et al. 1982) or 150 to $200 \mathrm{~nm}$ in diameter (Pichot 1986), and spores have dense vesicles 100 to $500 \mathrm{~nm}$ and haplosporosomes 120 to $150 \mathrm{~nm}$ in diameter (Pichot et al. 1979), or haplosporosomes 110 to $350 \mathrm{~nm}$ in diameter (Bachère \& Grizel 1983). At 200 to 269 nm in diameter, the plasmodial haplosporosomes in this study fall within the range of previous studies. Haplosporosomes with a hollow centre in transverse section, and an axehead shape have been previously illustrated from $H$. armoricanum only once, in 2 haplosporosomes in one spore (Fig. 6 in Cahour et al. 1980). This contrasts with the spores observed here in which every spore contained several axehead-shaped haplosporosomes, which were circular and hollow in transverse section. The axehead-shaped haplosporosomes were also much larger than those previously reported from $H$. armoricanum, but are similar in shape to the axeheadshaped haplosporosomes of $H$. costale (Figs. 21 to 23 in Perkins 1969) and an H. costale-like organism (Fig. 2 in Comps \& Pichot 1991), which are smaller at 350 to 650 nm (Perkins 1969) or 300 nm (Comps \& Pichot 1991) long, with a head 140 to $220 \mathrm{~nm}$ in diameter (Perkins 1969). The small round lucent patch with a dark point near the middle of the lucent patch has not been previously reported, although a haplosporosome in the lower right-hand quadrant of one spore (Fig. 6 in Cahour et al. 1980) appears to contain a similar structure.

The dense bodies were peripheral against the sporoplasm plasma membrane or lying outside it, and they appeared to pass out of the spores. Similar dense bodies array themselves peripherally in Haplosporidium lusitanicum (Fig. 5 in Azevedo 1984, Fig. 5 in Azevedo \& Corral 1985, Fig. 10 in Azevedo \& Corral 1987) and H. montforti (Fig. 1B in Azevedo et al. 2006), and in $H$. lusitanicum (Fig. 6 in Azevedo \& Corral 1987), H. pickfordi (Fig. 12 in Burreson 2001), and H. armoricanum (Fig. 7 in Azevedo et al. 1999) they often lie between the endosporoplasm and the spore wall. Similarly, $H$. costale (Fig. 21 in Perkins 1969) passes dense bodies between the opercular valves, and an $H$. costale-like species (Fig. 2 in Comps \& Pichot 1991) and B. perspora (Fig. 16 in Carnegie et al. 2006) eject haplosporosomes into the extrasporal space. Cytochemical analysis of $H$. lusitanicum dense bodies shows that they comprise glycoproteins (Azevedo \& Corral 1985, 1987) and lipid, and haplosporosomes contain glycoproteins with a lipoidal inner membrane and glycoproteinaceous exterior membrane (Azevedo \& Corral 1985).
Dense bodies and haplosporosomes may be lytic to surrounding tissues, or simply waste products.

Overall, Haplosporidium armoricanum is most similar to $H$. costale in the cup-like indentations on the nuclear surface (Perkins 1969), ejection of dense bodies/haplosporosomes (Comps \& Pichot 1991), and particularly the axe head shape of haplosporosomes in the plasmodia and spores (Perkins 1969, Comps \& Pichot 1991). However ultrastructural studies on H. costale (Perkins 1979), and an H. costale-like organism (Comps \& Pichot 1991), have not reported NMBG in any stage. $H$. armoricanum resembles $H$. lusitanicum in the formation of membranes to delimit the sporoblasts (Azevedo et al. 1985), arrangement of dense bodies at the sporoplasm periphery (Azevedo 1984, Azevedo \& Corral 1985, 1987), and their ejection into the extrasporal space (Azevedo et al. 1999). It also resembles Bonamia spp. in the cup-like nuclear indentations (Hine 1991, Hine \& Wesney 1992), ergastoplasm/mitochondrial complexes (Carnegie et al. 2006), MVBs (Hine \& Wesney 1992), formation of membranes to delimit sporoblasts, and NM-BG in the sporoplasm (Carnegie et al. 2006). The spores of $H$. armoricanum illustrated here superficially resemble those of $H$. costale more closely than $H$. armoricanum, suggesting that the 2 species are closely related, as is reflected in molecular phylogenies (M. Y. Engelsma, N. A. Stokes, P. M. Hine unpubl.).

\section{LITERATURE CITED}

Anderson TJ, Newman LJ, Lester RJG (1993) Light and electron microscope study of Urosporidium cannoni n. sp. haplosporidian parasite of the polyclad turbellarian Stylochus sp. J Eukaryot Microbiol 40:162-168

Azevedo C (1984) Ultrastructure of the spore of Haplosporidium lusitanicum sp. n. (Haplosporida, Haplosporidiidae), parasite of a marine mollusc. J Parasitol 70:358-371

Azevedo C, Corral L (1985) Cytochemical analysis of the haplosporosomes and vesicle-like droplets of Haplosporidium lusitanicum (Haplosporida, Haplosporidiidae), parasite of Helcion pellucidus (Prosobranchia). J Invertebr Pathol 46: 281-288

Azevedo C, Corral L (1987) Fine structure, development and cytochemistry of the spherulosome of Haplosporidium lusitanicum (Haplosporida). Eur J Protistol 23:89-94

Azevedo C, Corral L, Perkins FO (1985) Ultrastructural observations of spore excystment, plasmodial development and sporoblast formation in Haplosporidium lusitanicum (Haplosporida, Haplosporidiidae). Z Parasitenkd 71:715-726

Azevedo C, Montes J, Corral L (1999) A revised description of Haplosporidium armoricanum, parasite of Ostrea edulis L. from Galicia, northwestern Spain, with special reference to the spore-wall filaments. Parasitol Res 85:977-983

Azevedo C, Balseiro P, Casal G, Gestal C and 6 others (2006) Ultrastructural and molecular characterization of Haplosporidium montforti, n. sp., parasite of the European abalone Haliotis tuberculata. J Invertebr Pathol 92:23-32

Bachère E, Grizel H (1983) Mise en évidence d'Haplosporidium sp. (Haplosporida-Haplosporidiidae) parasite de 
l'huître plate Ostrea edulis. Rev Trav Inst Pêches Marit 46: 226-232

Bearham D, Spiers Z, Raidal S, Jones JB, Nicholls PK (2007) Molecular characterization of a haplosporidian parasite infecting rock oysters Saccostrea cuccullata in northern Western Australia. J Invertebr Pathol 95:33-40

Bonami JR, Vivarès CP, Brehélin M (1985) Étude d'une nouvelle haplosporidie parasite de l'huitre plate Ostrea edulis L.: morphologie et cytology de différents stades. Protistologica 21:161-173

Burreson EM (2001) Spore ornamentation of Haplosporidium pickfordi Barrow, 1961 (Haplosporidia), a parasite of freshwater snails in Michigan, USA. J Eukaryot Microbiol 48:622-626

Cahour A, Poder M, Balouet G (1980) Présence de Minchinia armoricana (Haplosporea, Haplosporida) chez Ostrea edulis d'origine francaise. C R Soc Biol 174:359-368

Carnegie RB, Burreson EM, Hine PM, Stokes NA, Audemard C, Bishop MJ, Peterson, PH (2006) Bonamia perspora n. sp. (Haplosporidia), a parasite of the oyster Ostreola equestris, is the first Bonamia species known to produce spores. J Eukaryot Microbiol 53:1-14

Carson FL, Martin JH, Lynn JA (1973) Formalin fixation for electron microscopy: a re-evaluation. Am J Clin Pathol 59: 365-373

Ciancio A, Srippa S, Izzo C (1999) Ultrastructure of vegetative and sporulation stages of Haplosporidium ascidiarium from the ascidian Ciona intestinalis L. Eur J Protistol 35: 175-182

Comps M, Pichot Y (1991) Fine spore structure of a haplosporidan parasitizing Crassostrea gigas: taxonomic implications. Dis Aquat Org 11:73-77

Comps M, Tigé G (1997) Fine structure of Minchinia sp., a haplosporidan infecting the mussel Mytilus galloprovincialis. Syst Parasitol 38:45-50

Hine PM (1991) Ultrastructural observations on the annual infection pattern of Bonamia sp. in flat oysters Tiostrea chilensis. Dis Aquat Org 11:163-171

Hine PM, Thorne T (2002) Haplosporidium sp. (Alveolata: Haplosporidia) associated with mortalities among rock oysters Saccostrea cuccullata in north Western Australia. Dis Aquat Org 51:123-133

Hine PM, Wesney B (1992) Interrelationships of cytoplasmic structures in Bonamia sp. (Haplosporidia) infecting oysters Tiostrea chilensis: an interpretation. Dis Aquat Org 14: 59-68

Hine PM, Cochennec-Laureau N, Berthe FCJ (2001) Bonamia exitiosus n. sp. (Haplosporidia) infecting flat oysters Ostrea chilensis in New Zealand. Dis Aquat Org 47:63-72

Hine PM, Wakefield S, Diggles BK, Webb VL, Maas EW (2002) Ultrastructure of a haplosporidian containing Rickettsiae, associated with mortalities among cultured paua Haliotis iris. Dis Aquat Org 49:207-219

La Haye CA, Holland ND, McLean N (1984) Electron microscopic study of Haplosporidium comatulae n. sp. (Phylum

Editorial responsibility: Richard Cawthorn, Charlottetown, Prince Edward Island, Canada
Ascetospora: Class Stellatosporea), a haplosporidian endoparasite of an Australian crinoid, Oligometra serripinna (Phylum Echinodermata). Protistologica 20:507-515

Marchand J, Sprague V (1979) Ultrastructure de Minchinia cadomensis sp.n. (Haplosporida) parasite du décapode Rhithropanopeus harrisii tridentatus Maitland dans le canal de Caen à la mer. J Protozool 26:179-185

Newman MW, Johnson CA, Pauley GB (1976) A Minchinialike haplosporidan parasitizing blue crabs, Callinectes sapidus. J Invertebr Pathol 27:311-315

Perkins FO (1968) Fine structure of the oyster pathogen Minchinia nelsoni (Haplosporida, Haplosporidiidae). J Invertebr Pathol 10:287-307

Perkins FO (1969) Electron microscope studies of sporulation in the oyster pathogen, Minchinia costalis (Sporozoa: Haplosporida). J Parasitol 55:897-920

Perkins FO (1971) Sporulation in the trematode hyperparasite Urosporidium crescens de Turk, 1940 (Haplosporida: Haplosporidiidae) - an electron microscope study. J Parasitol 57:9-23

Perkins FO (1975) Fine structure of Minchinia sp. (Haplosporida) sporulation in the mud crab, Panopeus herbstii. Mar Fish Rev 37:46-60

Perkins FO (1979) Cell structure of shellfish pathogens and hyperparasites in the genera Minchinia, Urosporidium, Haplosporidium and Marteilia-taxonomic implications. Mar Fish Rev 41:25-37

Perkins FO, van Banning P (1981) Surface ultrastructure of spores in three genera of Balanosporida, particularly Minchinia armoricana van Banning, 1977 - the taxonomic significance of spore wall ornamentation in the Balanosporida. J Parasitol 67:866-874

Perkins FO, Zwerner DE, Dias RK (1975) The hyperparasite, Urosporidium spisuli sp. n. (Haplosporea), and its effects on the surf clam industry. J Parasitol 61:944-949

Pichot Y (1986) Sporulation d'Haplosporidium sp. (Haplosporida, Haplosporidiidae) chez l'huître Ostrea edulis L. du basin d'Arcachon. In: Vivarès CP, Bonami JR, Jaspers E (eds) Pathology in marine aquaculture. European Aquaculture Society, Spec Publ No. 9. Bredene, p $119-126$

Pichot Y, Comps M, Deltreil JP (1979) Recherches sur Haplosporidium sp. (Haplosporida-Haplosporidiidae) parasite de l'huître plate Ostrea edulis. Rev Trav Inst Pêches Marit 43:405-408

Rosenfield A, Buchanan L, Chapman GB (1969) Comparison of the fine structure of spores of three species of Minchinia (Haplosporida, Haplosporidiidae). J Parasitol 55:921-941

van Banning P (1977) Minchinia armoricana sp. nov. (Haplosporida), a parasite of the European flat oyster, Ostrea edulis. J Invertebr Pathol 30:199-206

Vivarès CP, Brehélin M, Cousserans F, Bonami JR (1982) Mise en évidence d'une nouvelle Haplosporidie parasite de l'huître plate Ostrea edulis L. C R Acad Sci Ser III 295: $127-130$

Submitted: September 26, 2006; Accepted: May 20, 2007 Proofs received from author(s): September 24, 2007 